\title{
Simulation Production of Dimethylether (DME) from Dehydration of Methanol Using Aspen Hysys
}

Ezeddin H. Alshbuki ${ }^{1}$, Mufida M. Bey ${ }^{2}$, Abduraouf ALAmer Mohamed ${ }^{3}$

${ }^{1,2}$ Sabratha Uuniversity, Faculty of Engineering, Sabratha - Libya

${ }^{3}$ Zawia Uuniversity, Faculty of Science, Zawia - Libya

DOI: $10.36348 /$ sijcms.2020.v03i02.002

| Received: 18.02.2020 | Accepted: 25.02.2020 | Published: 29.02.2020

*Corresponding author: Abduraouf ALAmer Mohamed

Abstract

Dimethyl ether (DME) is used primarily as a propellant and a motor fuel alternative, (DME) is miscible with most organic solvents and has a high solubility in water. Recently, the use of (DME) as a fuel additive for diesel engines has been investigated due to its high volatility (desired for cold starting) and high cetane number of 55-60, with the advantage of high efficiency, and low exhaust emissions (no particulates, no Sulphur, and low NOx). Technical-quality (DME) is an alternative to liquefied petroleum gas (LPG). The production processes included catalytic dehydration of methanol in an adiabatic fixed-bed reactor and two columns product separations. In this study, the technological process for (DME) synthesis is simulated in Aspen Hysys V3.1 based on the combined parameters of the reaction dynamic model for methanol dehydration reaction, the improved NRTL model of the liquid phase, the PR model of vapor phase was selected as the fluid package as it is able to handle selected pure components (methanol, water and dimethyl ether). The equilibrium reaction was selected to describe conversion of methanol to DME reaction and it is about $80 \%$. A feasibility study and design of a plant producing $99.9 \mathrm{wt} \%$ Dimethyl ether (DME). The plant is designed which is capable of producing 50,000 metric tons of (DME) per year via the catalytic dehydration of methanol over an acid zeolite catalyst.

Keywords: dehydration, Aspen Hysys, simulation, Dimethyl ether, production.

Copyright @ 2020: This is an open-access article distributed under the terms of the Creative Commons Attribution license which permits unrestricted use, distribution, and reproduction in any medium for non-commercial use (NonCommercial, or CC-BY-NC) provided the original author and source are credited.

\section{INTRODUCTION}

Simulation is a situation in which a particular set of conditions is created artificially in order to study or experience something that could really exist in reality. It is the act if pretending that something is real when it is not. A computer simulation is an attempt to model a real-life or hypothetical situation on a computer so that it can be studied to see how the system works.

Process simulator is defined also as an engineering tool which performs automated calculations, mass \&energy balances, physical property estimations, design / rating calculations, costing, process optimization, accurate description of physical properties of pure components and complex mixture, models for a large variety of reactors and unit operations, numerical techniques for solving large systems of algebraic and differential equations [1].

In this work Aspen HysysV3.1 used to simulate production of DME. There are two modes of simulation- Steady state mode and Dynamic mode. Steady state models perform a mass and energy balance of a stationary process (a Process in an equilibrium state) but any changes over time had to be ignored. Dynamic simulations require increased calculation time and are mathematically more complex than a steady state simulation. It can be seen as a multiply repeated steady state simulation (based on a fixed time step) with constantly changing parameters.

Aspen HYSYS is a market leading process modeling tool for conceptual design, optimization, business planning, asset management and performance monitoring for oil in gas processing, petroleum refining, and air separation industries. Aspen HYSYS is a core element of Aspen Tech's aspen ONE Engineering applications. Aspen HYSYS has established itself as a very intuitive and easy to use process simulator in oil and gas refining industry. Users with little prior knowledge of Aspen HYSYS can pick up and train themselves in its modeling capabilities. Some of the very intuitive capabilities include a highly interactive process flow diagram for building and navigating through large simulations. The program also provides a very flexible and easy to use distillation column 
modeling environment. Additionally the interactive nature of HYSYS enables users to build and use their models quickly and effectively. Aspen HYSYS offers a comprehensive thermodynamics foundation for accurate calculation of physical properties, transport properties, and phase behavior for the oil \& gas and refining industries. Comprehensive library of unit operation models including distillation, reactors, heat transfer operation, rotating equipments, controllers and logical operations in both the steady state and dynamic environments $[2,3]$.

Dimethyl ether (DME), as a multi-source, multi-purpose product, has received growing attention due to the present global environmental pollution and energy supply problems. DME can be produced from syngas, which in turn is formed from natural gas, coal or biomass. DME has a wide range of applications such as LPG substitute,

Propellant, chemical feedstock and transportation fuel, and in fuel cells [4, 5]. Catalytic dehydration of methanol over an acidic catalyst offers a potential method for the production of DME, a new spray propellant. Being identified as a potential diesel and cooking fuel, DME has many excellent characteristics. It has the oxygen content of $34.78 \%$ and can be burned without soot emission, whereas for traditional diesel fuels, simultaneous NOx and soot emission control target cannot be expected. It has a boiling point of $-25^{\circ} \mathrm{C}$, which is $20^{\circ} \mathrm{C}$ higher than LPG and can be liquefied at $0.54 \mathrm{MPa}\left(20^{\circ} \mathrm{C}\right)$. Therefore, based on the matured technology of LPG application, as far as storage, transportation, and usage, no remarkable problem for the use of DME exists $[5,6]$.

DME also known as methoxy methane, wood ether, diethyl oxide or methyl ether, is the simplest ether. It is a colorless, slightly narcotic, nontoxic, highly flammable gas at ambient conditions, but can be handled as a liquid when lightly pressurized. The properties of DME are similar to those of Liquefied Petroleum Gas (LPG).

Low cost technologies for DME have been mainly carried out by JFE Group (Japan), Haldor Topsoe (Denmark) in Europe, Air Products and Chemicals in the United States, and others. The use of DME as an alternative fuel will be crucial in China, a country with so high pollution rates, in the near future.

Sweden is the leader in the development of bio-DME produced through the gasification and conversion of black liquor, a byproduct in Sweden's paper and pulp industry.

The production of DME in Spain is mainly carried out by aerosol and fuel industry. Due to its global increasing importance regarding energy and environmental advantages, as well as the proper personal interest in the topic, DME synthesis process was selected in this graduation project. Nowadays, the indirect synthesis of dimethyl ether is the conventional production method in the industry. Conditions may be correctly defined and controlled, but it takes two main synthesis steps in the process, whereas direct synthesis has been recently researched and is about to be implemented as a higher performance method that occurs in one synthesis step [7].

Currently, there are several licensors that offer technology for the production of DME based on a twostep process, including Haldor Topsøe, Lurgi, Mitsubishi Gas Chemical, Toyo Engineering Corporation and Uhde [8].

DME synthesis is a two-stage process. In the first step, methanol production is catalyzed over $\mathrm{CuO} / \mathrm{ZnO} / \mathrm{Al}_{2} \mathrm{O}_{3}$ at $50-100$ bar and $270^{\circ} \mathrm{C}$. In a second step, $\mathrm{CH}_{3} \mathrm{OH}$ is dehydrated in the presence of an acid zeolite or Lewis acidic catalyst, such as $\mathrm{Al}_{2} \mathrm{O}_{3}$, ZSM-5

The reaction of DME synthesis is mainly dehydration of methanol that is exothermic and reversible. In the current work, the rate expression has been selected from $[9,10]$.

Methanol dehydration reaction:

$$
2 \mathrm{CH}_{3} \mathrm{OH} \leftrightarrows \mathrm{CH}_{3} \mathrm{OCH}_{3}+\mathrm{H}_{2} \mathrm{O}
$$

\section{THERMODYNAMIC MODEL SELECTION}

An important consideration in distillation simulation is the choice of physical equilibrium model and the ability to reliably predict the multi-component vapor- -liquid equilibrium (VLE). Reliable VLE are needed to establish distillation boundaries and to determine if and where azeotrope and phase separation occurs. Several equations can be used to model DMEmethanol-water system such as Van Laar, Margules, Wilson, NRTL, UNIQUAC.

The NRTL equation was developed by Renon and Prausnitz to make use of the local composition concept while avoiding the Wilson equation's inability to predict liquid-liquid phase separation. The resulting equation correlates the liquid activity coefficient for each binary in terms of three parameters. This method has been used extensively to fit a wide variety of VLE and LLE systems.

NRTL model was recommended by Song Huaijun [11] and binary interaction parameters of DME-methanol, DME -water, methanol-water obtained from experiments were introduced in (Table 1).

Equations of multi-systems activity coefficient:

$$
\operatorname{lng} g_{i}=\frac{\sum_{j} t_{j i} G_{j i} x_{j}}{\sum_{k} G_{k i} x_{k}}+\sum_{j} \frac{x_{j} G_{i j}}{\sum_{k} G_{k i} x_{k}}\left[t_{i j}-\frac{\sum_{k} x_{k} t_{k j} G_{K J}}{\sum_{k} G_{k j} x_{k}}\right]
$$


In equation (2),

$$
\begin{gathered}
t_{i j}=a_{i j}+\frac{b_{i j}}{T T}+\frac{c_{i j}}{2} \quad(\text { unit is } K) \\
G_{i j}=\exp \left(-a_{j i} t_{j i}\right), a_{j i}=a_{j i}+b_{j i} T
\end{gathered}
$$

And vapor phase properties are calculated from the Peng-Robinson equation of state. The PengRobinson equation of state (PR) is a modification of the Redlich-Kwong equation of state and was published by Peng and Robinson in 1976. Only the critical data of pure substance are a prerequisite for application due to the plain pattern and the generalized parameters for PR equation. Moreover, analytical solutions could be observed mathematically, which makes PR equation widely applied in engineering. The expression is as follows [12]:

$$
P=\frac{R T}{(V-b)}-\frac{\theta_{P R}}{V^{2}+2 b V-b^{2}}
$$

In equation (3),

$$
\begin{gathered}
\theta_{P R}=a^{\prime \prime}[1+(0.37464+1.54226 \omega \\
\left.\left.-0.26992 \omega^{2}\right)\left(1-T_{r}^{0.5}\right)\right]^{2} \\
a^{\prime \prime}=\frac{0.45724 R^{2} T_{c}^{2}}{P_{c}} \\
b=\frac{0.07780 R T_{c}}{P_{c}}
\end{gathered}
$$

Table 1. Eight constants of NRTL binary interaction parameters
\begin{tabular}{|l|c|c|c|c|c|c|c|c|c|}
\hline Component $\mathrm{i}$ & $\mathrm{Componentj}$ & $\mathrm{a}_{\mathrm{ij}}$ & $\mathrm{b}_{\mathrm{ij}}$ & $\mathrm{c}_{\mathrm{ij}}$ & $\mathrm{a}_{\mathrm{ij}}$ & $\mathrm{b}_{\mathrm{i}}$ & $\mathrm{c}_{\mathrm{i}}$ & $\mathrm{a}_{\mathrm{ij}}$ & $\beta_{\mathrm{ij}}$ \\
\hline $\mathrm{DME}$ & $\mathrm{CH}_{3} \mathrm{OH}$ & 1.1352 & -785.15 & 182686 & -0.0652 & 138.01 & 1.7135 & 0.3 & 0 \\
\hline $\mathrm{DME}$ & $\mathrm{H}_{2} \mathrm{O}$ & 13.402 & -6561.2 & 974420 & 12.174 & -6936.5 & 1108017 & 0.3 & 0 \\
\hline $\mathrm{CH}_{3} \mathrm{OH}$ & $\mathrm{H}_{2} \mathrm{O}$ & -1.8713 & 481.43 & 7592.5 & 3.3323 & -689.48 & 39.157 & 0.3 & 0 \\
\hline
\end{tabular}

\section{REACTION KINETICS}

The reaction equation of DME synthesis from dehydrogenation of methanol was listed in equation (1).

$$
\begin{gathered}
r_{M}=-\frac{d N_{M}}{d W}=1457.024 e^{-\frac{78072.55}{R T}} f_{M}^{0.55}\left(1-\frac{f_{D} f_{w}}{K_{f} f_{M}^{2}}\right) \\
r_{D}=-\frac{d N_{D}}{d W}=\frac{r_{M}}{2}
\end{gathered}
$$

The reaction taking place is mildly exothermic with a standard heat of reaction of $-21,225 \mathrm{KJ} / \mathrm{mol}$. The equilibrium constant for this reaction at three different temperatures is given below:

Table-2: Equilibrium constant

\begin{tabular}{|c|c|}
\hline $\mathbf{T}$ & $\mathbf{K}_{\mathbf{p}}$ \\
\hline $473 \mathrm{~K}\left(200^{\circ} \mathrm{C}\right)$ & 92.6 \\
\hline $573 \mathrm{~K}\left(300^{\circ} \mathrm{C}\right)$ & 52.0 \\
\hline $673 \mathrm{~K}\left(400^{\circ} \mathrm{C}\right)$ & 34.7 \\
\hline
\end{tabular}

The equilibrium conversions for pure methanol feed over the $200^{\circ} \mathrm{C}$ to $400^{\circ} \mathrm{C}$ range are all greater than $83 \%$. By limiting conversions to $80 \%$, the reaction will not be equilibrium limited.

\section{PROCESS DESCRIPTION}

DME is produced by dehydrogenation over an industrialized molecular sieve catalyst. The reaction temperature was set at between $200^{\circ} \mathrm{C}$ to $400^{\circ} \mathrm{C}$ and
The intrinsic kinetics equation of methanol dehydration to DME reaction can be expressed as [10]: dehydration reaction is carried out in a multistage adiabatic reactor. Methanol is introduced to the system at $25^{\circ} \mathrm{C}, 262 \mathrm{Kgmol}^{-1}$ and $100 \mathrm{KPa}$ from methanol synthesis plant.

Then the pressure is increased to $1400 \mathrm{KPa}$. The raw material is mixed with the recycle stream $R$ coming from the separation. This mixture is vaporized in the heater (see Fig. 1) and preheated in the heat exchanger (HE) before entering the reactor. Then the pressure is increased to $1400 \mathrm{KPa}$. The raw material is mixed with the recycle stream $\mathrm{R}$ coming from the separation. This mixture is vaporized in the heater (see Fig. 1) and preheated in the heat exchanger (HE) before entering the reactor.

After dehydration, the components in the stream consist of DME, $\mathrm{CH}_{3} \mathrm{OH}, \mathrm{H}_{2} \mathrm{O}$ and a smaller amount of $\mathrm{CO}, \mathrm{CO}_{2}, \mathrm{CH}_{4}, \mathrm{H}_{2}, \mathrm{C}_{2} \mathrm{H}_{5} \mathrm{OH}$, et al. The reactor exit stream is 


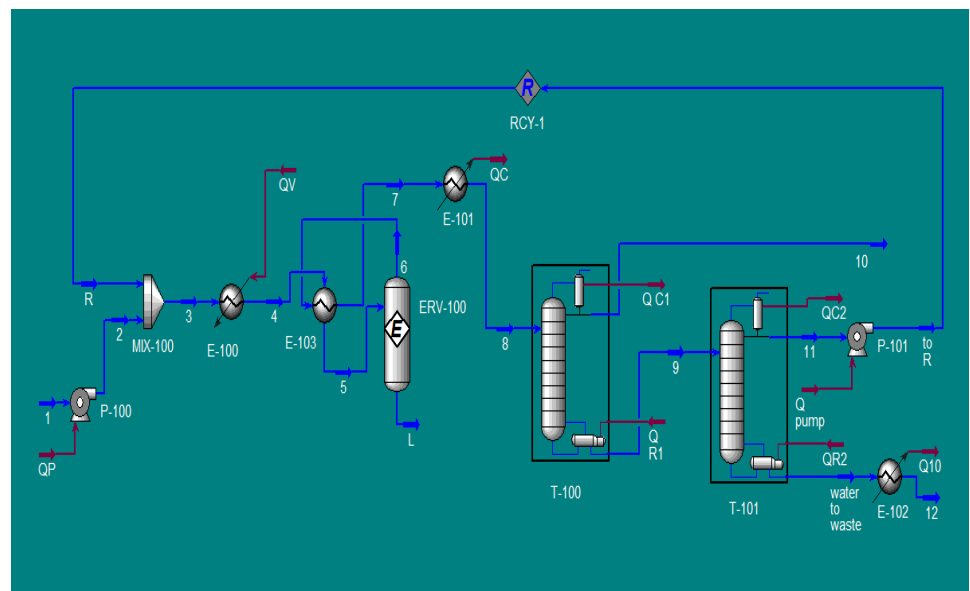

Fig-1: Process flow diagram of Production (DME) from Dehydration of Methanol

Cooled (Cooler), partially decompressed, and introduced in the separation train. DME is obtained in column T-100 with the purity higher than $99.9 \%$ (molar basis). The bottoms of column T-100 are decompressed again and introduced into a second distillation column that separates water from methanol.

Water is sent to a treatment section to remove traces of organic compounds, and the methanol recycled. The heat duty of the condenser in DME distillator is from engineering water, and any extra cryogen is undesired.

\section{RESULTS AND DISCUSSION}

The design capacity of the industrial DME production device from a factory is 50,000 metric tons of (DME) per year.
The data gathered from the manufacturing plant are introduced to perform the simulation results. In the reaction products, there is not only existed DME, $\mathrm{CH}_{3} \mathrm{OH}$ and $\mathrm{H}_{2} \mathrm{O}$, but smaller amounts of $\mathrm{CO}, \mathrm{CO}_{2}$, $\mathrm{CH}_{4}, \mathrm{H} 2, \mathrm{C}_{2} \mathrm{H}_{6} \mathrm{O}$ and $\mathrm{CH}_{3} \mathrm{CHO}$ could be found.

Table 3 shows the main parameters of the simulation, and, DME distillation column (column T100 in Fig. 1) consists of a 22 theoretical plates with a condenser and a reboiler. The optimum location for the DME distillation feed was determined by varying the feeding location. In case of meeting the DME purity requirement, making the reflux ratio, condenser duty and reboiler duty minimum, and the twelfth tray is the optimum feed position.

Table 4 shows properties and components of the main stream in the simulation process (component mol\%).

Table-3: The main parameters of the simulation

\begin{tabular}{|l|l|l|}
\hline Feed stream & Reactor & DME column \\
\hline Temperature: $25^{\circ} \mathrm{C}$ & Inlet temperature: $250^{\circ} \mathrm{C}$ & Column pressure: $1310 \mathrm{Kpa}$ \\
\hline Pressure: $100 \mathrm{Kpa}$ & Outlet temperature: $361.4^{\circ} \mathrm{C}$ & Condenser: Total condensation \\
\hline Flow rate: $262 \mathrm{Kgmol} . \mathrm{h}^{-1}$ & Pressure: $1480 \mathrm{Kpa}$ & Feed stage: 12 \\
\hline Feed composition: & Reactor length: $10 \mathrm{~m}$ & Total number of theoretical stages: 22 \\
\hline \multirow{2}{*}{$\begin{array}{l}\text { Methanol: } 99.01 \mathrm{~mol} \% \\
\text { DME: } 0\end{array}$} & Tube inside diameter: $0.720 \mathrm{~m}$ & Side product (liquid) stage: 2 \\
\cline { 2 - 3 } Water: $0.99 \mathrm{~mol} \%$ & Reactor volume: $4.072 \mathrm{~m}^{3}$ & Reflux ratio: 0.4590 \\
\cline { 2 - 3 } & Heat of reaction: $-20.896 \mathrm{KJ}_{\mathrm{mol}}{ }^{-1}$ & DME product purity: $99.9 \mathrm{~mol} \%$ \\
\hline
\end{tabular}

Table-4: Properties and components of the main stream in the simulation process (component mol\%)

\begin{tabular}{|l|c|c|c|c|c|c|}
\hline Stream & DME & $\mathbf{C H}_{\mathbf{3}} \mathbf{O H}$ & $\mathbf{H}_{\mathbf{2}} \mathbf{O}$ & $\mathbf{T} / \mathbf{C}^{\circ}$ & $\mathbf{P} / \mathbf{K p a}$ & Flow/Kgmolh $^{-1}$ \\
\hline 1 & 0.0000 & 0.9905 & 0.0095 & 25.000 & 100.00 & 262.20 \\
\hline 2 & 0.0000 & 0.9905 & 0.0095 & 25.850 & 1550.0 & 262.20 \\
\hline 3 & 0.0029 & 0.9887 & 0.0084 & 42.730 & 1550.0 & 314.90 \\
\hline 4 & 0.0029 & 0.9887 & 0.0084 & 153.30 & 1500.0 & 314.90 \\
\hline 5 & 0.0029 & 0.9887 & 0.0084 & 250.00 & 1480.0 & 314.90 \\
\hline 6 & 0.4149 & 0.1649 & 0.4202 & 361.40 & 1400.0 & 314.90 \\
\hline 7 & 0.4149 & 0.1649 & 0.4202 & 272.80 & 1350.0 & 314.90 \\
\hline 8 & 0.4149 & 0.1649 & 0.4202 & 90.080 & 1310.0 & 314.90 \\
\hline 9 & 0.0049 & 0.2798 & 0.7153 & 154.90 & 1050.0 & 185.10 \\
\hline 10 & 0.9990 & 0.0010 & 0.0000 & 46.220 & 1030.0 & 129.80 \\
\hline 11 & 0.0175 & 0.9800 & 0.0025 & 120.80 & 730.00 & 52.710 \\
\hline 12 & 0.0000 & 0.0010 & 0.9990 & 50.080 & 160.00 & 132.30 \\
\hline
\end{tabular}




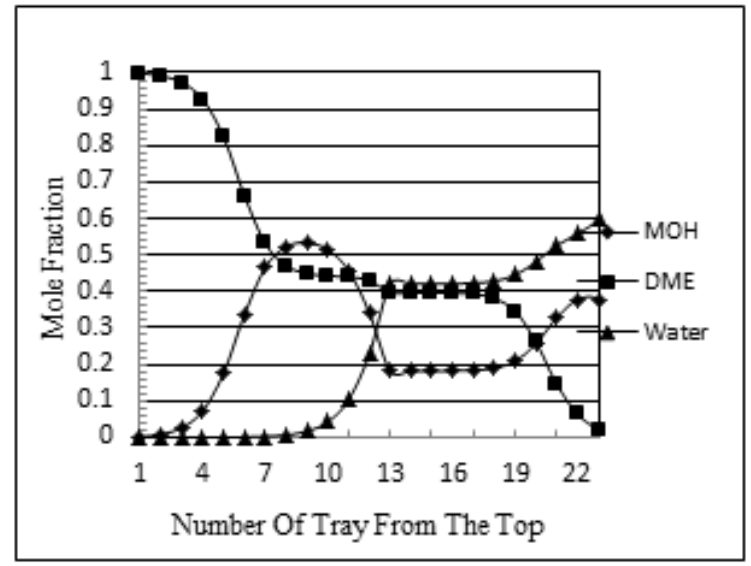

Fig-2: Composition versus tray position

Figure 2 shows change of composition versus tray position. The composition of DME decreases with increase of number of theoretical trays distillation column T-100.

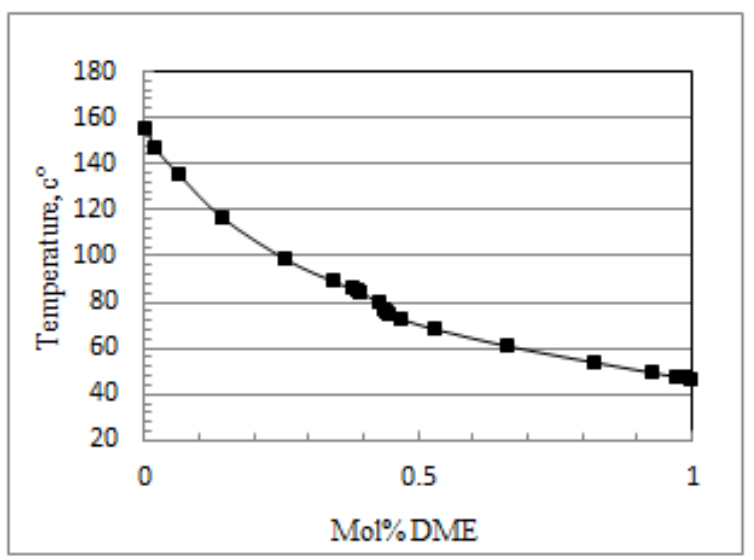

Fig-3: Change of temperature versus mol\% DME

And Figure 3 shows change of temperature of the same column with change of composition of DME.

\section{CONCLUSION}

Simulation of a DME plant which is capable of producing DME with high purity (50,000 tons per year) from methanol is done using ASPEN HYSYS V3.1 process simulator. NRTL is chosen as the property method in the simulation. $80 \%$ of the methanol is converted into DME in the equilibrium reactor, the product stream from the reactor consists of $41.16 \%$ DME, $42.16 \%$ water and $16.68 \%$ unconverted methanol. After passing through Heat exchangers (to bring down the temperature to the desired range for separation), the output stream is feed into distillation columns.

Here, the separation into DME and watermethanol takes place.DME is separated from the first distillation column as top product and methanol, water as bottom product, which fed into second distillation column.
Design specifications are used to meet the required results. The reflux ratios and the distillate rates are manipulated as variable parameters and the high purity of DME is obtained by using two distillation columns with four Heat exchangers.

\section{ACKNOWLEDGEMENTS}

The authors wish to thanks Sabratha Uuniversity for funding this project by all available information.

\section{NOMENCLATURE \\ $\mathrm{MOH}$ Methanol \\ DME Dimethyl ether \\ $t$ model parameter \\ $N$ mass flow rate, $\mathrm{Kgmol}^{-1} \mathrm{~h}^{-1}$ \\ $W \quad$ catalyst weight, $\mathrm{Kg}$ \\ $g \quad$ activity coefficients \\ $V$ molar volume, $\mathrm{m} 3 . \mathrm{mol}^{-1}$ \\ $R \quad$ universal gas constant, $\mathrm{J} \cdot \mathrm{mol}^{-1} \cdot \mathrm{K}^{-1}$ \\ $G \quad$ mixed Gibbs function, KJ.mol ${ }^{-1}$ \\ $f \quad$ fugacity, Kpa \\ $K_{p} \quad$ equilibrium constant \\ $r \quad$ reaction rate, mol. $\mathrm{Kg}^{-1} \cdot \mathrm{h}^{-1}$}

$\begin{array}{ll}\text { Subscripts } \\ \text { c } & \text { critical state } \\ \text { D } & \text { dimethyl ether } \\ \text { M } & \text { methanol } \\ \text { r } & \text { constant } \\ \text { W } & \text { water }\end{array}$

\section{REFERENCES}

1. Martin, B., Hans, J. W. (2001). Friedrich Schmidt, Methanol Utilization Technologies.

2. Hamid, A., \& Kamaruddin, M. (2007). HYSYS: an introduction to chemical engineering simulation for UTM Degree++ program. Michael, H.E. (2007). "Chemical Process Simulation and Aspen tech Hysys Software” Version 2006 Bucknell university Lewisburg PA 17837 December 152007.

3. Ng, K. L., Chadwick, D., \& Toseland, B. A. (1999). Kinetics and modelling of dimethyl ether synthesis from synthesis gas. Chemical Engineering Science, 54(15-16), 3587-3592.

4. Lu, W. Z., Teng, L. H., \& Xiao, W. D. (2003). Theoretical analysis of fluidized-bed reactor for dimethyl ether synthesis from syngas. International Journal of Chemical Reactor Engineering, 1(1).

5. Flesch, T., McCarthy, C., Basu, A., \& Udovich, C. (1995). "A New Clean Diesel Technology: Demonstration of ULEV Emissions on a Navistar Diesel Engine Fueled with Dimethyl Ether," SAE paper 950061. In Proceedings of the International Congress and Exposition.

6. Fleisch, T. H., Basu, A., \& Sills, R. A. (2012). Introduction and advancement of a new clean global fuel: The status of DME developments in China and beyond. Journal of Natural Gas Science and Engineering, 9, 94-107. 
7. Kumar, M., \& Srivastava, V. C. (2010). Simulation of a Fluidized- Bed Reactor for Dimethyl Ether Synthesis. Chemical engineering

\& technology, 33(12), 1967-1978.

8. Bohnenn, L. J. M. (1981). Dimethylether pure: a review. Aerosol Age, 26(1), 26.

9. Ziyang Bai, Hongfang Ma, Haitao Zhang, Weiyong Ying, Dingye Fang, TPeoclhis. h, VJolu. rn15a,1
Nofo C. 2h,e m20ic1a31 Technology, 15, 2, 122 127, 10.2478/pjct-2013-0034.

10. Song, H.J., Zhang, H.T., Ying, W.Y., \& Fang, D.Y. (2005). Measurement and calculation of vaporliquid equilibrium for dimethylether-methanolwater ternary system. Journal of Chemical Industry and Engineering (China) 30, 67-71.

11. Smith, J. M. (1950). Introduction to chemical engineering thermodynamics. 